\title{
Hypoxia May Increase Rat Insulin mRNA Levels by Promoting Binding of the Polypyrimidine Tract-binding Protein (PTB) to the Pyrimidine-rich Insulin mRNA 3'-Untranslated Region
}

\author{
Linda Tillmar and Nils Welsh \\ Department of Medical Cell Biology, Uppsala University, Uppsala, Sweden \\ Accepted May 6, 2002
}

\begin{abstract}
Background: Recent reports identify the $3^{\prime}$-UTR of insulin mRNA as crucial for control of insulin messenger stability. This region contains a pyrimidine-rich sequence, which is similar to the hypoxia-responsive mRNA-stabilizing element of tyrosine hydroxylase. This study aimed to determine whether hypoxia affects insulin mRNA levels.

Materials and Methods: Rat islets were incubated at normoxic or hypoxic conditions and with or without hydrogen peroxide and a nitric oxide donor. Insulin mRNA was determined by Northern hybridization. Islet homogenates were used for electrophoretic mobility shift assay with an RNA-oligonucleotide, corresponding to the pyrimidinerich sequence of the 3'-UTR of rat insulin I mRNA. The expression of reporter gene mRNA, in islets transfected with reporter gene constructs containing the wild-type or mutated insulin mRNA pyrimidine-rich sequences, was measured by semiquantitive RT-PCR.
\end{abstract}

Results: Insulin mRNA was increased in response to hypoxia. This was paralleled by increased binding of the polypyrimidine tract-binding protein (PTB) to the pyrimidine-rich sequence of the $3^{\prime}$-UTR of insulin mRNA, which was counteracted by hydrogen peroxide. The reporter gene mRNA level containing the wild-type binding site was not increased in response to hypoxia, but mutation of the site resulted in a destabilization of the mRNA.

Conclusions: The complete understanding of different diabetic conditions requires the elucidation of mechanisms that control insulin gene expression. Our data show that hypoxia may increase insulin mRNA levels by promoting the binding of PTB to the insulin mRNA 3'-UTR. Hydrogen peroxide abolishes the hypoxic effect indicating involvement of reactive oxygen species and/or the redox potential in the oxygen-signaling pathway.

\section{Introduction}

We recently demonstrated that insulin mRNA is highly abundant and constitutes up to $30 \%$ of the pancreatic beta cell mRNA (1). The insulin mRNA is also especially long-lived, 29-77 hr, depending on glucose concentration (2), and its stability is therefore likely to be regulated by specific mechanisms. A recent study has identified the 3 '-untranslated region ( $3^{\prime}$-UTR) as critical for beta cell-specific glucose-mediated control of rat insulin II mRNA (3). In addition, we have observed that the $3^{\prime}$-UTR of rat insulin mRNA contains an active RNAstabilizing element, the insulin mRNA 3 '-UTR pyrimidine-rich sequence (ins-PRS), to which the polypyrimidine tract-binding protein (PTB) binds (1). This binding is increased in response to glucose as well as to reducing agents (1). PTB exists in at least three isoforms, with molecular masses ranging from 55-62 kDa. It belongs to the heterogeneous nuclear ribonucleoprotein (hnRNP) family, and is also known as hnRNP-I (4). In addition to the three

Correspondence and reprint requests should be addressed to: Linda Tillmar, Department of Medical Cell Biology, Uppsala University, Biomedicum, P.O. Box 571, SE-751 23 Uppsala, Sweden. Phone: +46-(0)18 4714395; fax: +46-(0) 18 556401; e-mail: Linda.Tillmar@medcellbiol.uu.se. different isoforms, there is a neuronal form of PTB (nPTB) $(5,6)$. PTB may assist in transcription (7), translation (8), polyadenylation $(9,10)$, and subcellular localization (11) of mRNA. The main function described so far, however, seems to be to repress mRNA splicing (12). PTB mRNA levels in insulinproducing MIN6-cells are increased 5-fold in response to a 24-hr incubation at a high glucose concentration (13). In addition, PTB protein contents have been reported to be up-regulated 3 -fold in rat islets when challenged with interleukin-1 (14). This may indicate that the expression of PTB is controlled in a cell-specific manner and that PTB contributes to the beta cell phenotype as a glucoseresponsive regulator of insulin biosynthesis. PTB is known to interact with other members of the hnRNP family such as hnRNP-E2 and -K (8). HnRNP$\mathrm{E}$ is a 36- to $42-\mathrm{kDa}$ protein, also known as $\alpha \mathrm{CP}$ or the poly $(C)$ binding protein $(\mathrm{PCBP})(15,16)$. Some PCBP isoforms are thought to regulate the stabilities of the messengers coding for tyrosine hydroxylase (TH) (17), erythropoietin (18), $\alpha$ - and $\beta$-globin $(19,20), \alpha(\mathrm{I})$-collagen, and 15-lipoxygenase (20). It appears that PCBP binds to an element referred to as the hypoxia-inducible protein-binding site (HIPBS) located in the 3'-UTR of TH mRNA. This event has been shown to be necessary, but not 
sufficient, for both constitutive and hypoxia-mediated stability of this mRNA (17).

In view of the close homology between TH HIPBS and the insulin mRNA 3'-UTR (1), the aim of the present study was to determine whether insulin mRNA levels are affected by hypoxia and, if so, if this is paralleled by an altered PTB-ins-PRS interaction.

\section{Material and Methods}

\section{Isolation and Culture of Pancreatic Islets}

Adult Sprague-Dawley rats from a local colony were killed by cervical dislocation after an intraperitoneal injection of a sodium pentobarbital. The pancreases were taken out and the islets isolated by collagenase digestion (21). The islets were cultured in $5 \mathrm{ml}$ RPMI-1640, supplemented with 10\% Fetal Clone II serum (Hyclone Europe Ltd, Cramlington, UK), $2 \mathrm{mM}$ L-glutamine, $100 \mathrm{U} / \mathrm{ml}$ benzyl penicillin, and $0.1 \mathrm{mg} / \mathrm{ml}$ streptomycin (RPMI-WS). The islets were cultured free floating for 5-10 days with the medium changed every second day (21). Only small or medium sized islets were chosen for experimentation; cells located near the center of large islets often become necrotic due to insufficient diffusion of nutrients and/or oxygen. To produce hypoxia, 50-100 islets $/ 5 \mathrm{~cm}^{2}$ where cultured under a medium depth of 4-6 mm, in flasks containing $5 \mathrm{ml}$ of culture medium, which were flushed with $1 \%, 5 \%$ or $10 \%$ $\mathrm{O}_{2} / 5 \% \mathrm{CO}_{2} / 94 \%, 90 \%$, or $85 \% \mathrm{~N}_{2}$ for at least $20 \mathrm{~min}$ prior to the addition of islets. The flasks were incubated under airtight conditions. The oxygen tension in the culture media, following different gassing time periods and incubation periods, were verified using modified Clark microelectrodes (Unisense, Aarhus, Denmark) (22). These electrodes have a tip with a $2-$ to $6-\mu \mathrm{m}$ outer diameter and a $1-$ to $2-\mu \mathrm{m}$ inner diameter. The electrodes were polarized at $-0.800 \mathrm{~V}$, which gives a linear response between the oxygen tension and the electrode current. The electrodes were calibrated in water saturated with $\mathrm{NaS}_{2} \mathrm{O}_{5}$ or air at $37^{\circ} \mathrm{C}$. The baseline deviation of the recordings was $<0.5 \% / \mathrm{hr}$. The oxygen tensions were measured in the medium, at a depth of $3 \mathrm{~mm}$, and not in the immediate proximity of the islets. The oxygen tension was recorded in three different flasks per condition. To ensure hypoxia throughout a long-term incubation, flasks with islets incubated for 16-24 hours were gassed, sealed, and incubated in an airtight box, which was also gassed with the same gas mixture as the flasks.

\section{Assessment of Cell Viability in Response to Hypoxia}

Islets were incubated for $24 \mathrm{hr}$ at $21 \%, 10 \%, 5 \%$ or $1 \% \mathrm{O}_{2}$ and cell death was determined by staining with $20 \mu \mathrm{g} / \mathrm{ml}$ Hoechst 33342 (bisbenzimide) and $10 \mu \mathrm{g} / \mathrm{ml}$ propidium iodide (Sigma-Aldrich, St. Louise, MO, USA) for $10 \mathrm{~min}$ at $37^{\circ} \mathrm{C}(23)$. The islets were then examined with a fluorescence microscope, using an UV-2A filter. For the quantification of islet cell death, islets were trypsinized and analyzed by flow cytometry (FACS-Calibur, Becton-Dickinson, Oxford, UK) (24).

\section{Northern Hybridization Analysis}

Rat islets in groups of 50 were incubated for 6, 16 or $24 \mathrm{hr}$ as given in Figure 1. RNA was isolated using the Ultraspec Total RNA Isolation System (Biotech Laboratories, Houston, TX, USA) and analyzed by Northern hybridization. The samples were loaded on a $1.25 \%$ agarose gel and run for $1 \mathrm{hr}$ at $100 \mathrm{~V}$. Gels were washed with water to remove formaldehyde, stained with ethidium bromide, and photographed. The RNA was transferred to a nylon membrane and cross-linked by UV irradiation. The filter was then incubated in prehybridization buffer for $3 \mathrm{hr}$ at $42^{\circ} \mathrm{C}$. The buffer was exchanged for a buffer containing a radiolabeled insulin cDNA (25) and the membrane was incubated overnight at $42^{\circ} \mathrm{C}$. The insulin probe, pRI7, was labeled with $\left[\alpha-{ }^{32} \mathrm{P}\right]$ dCTP using the Mega Prime DNA labeling kit (Amersham Pharmacia Biotech, Uppsala, Sweden). The filter was washed and exposed to Hyperfilm MP (Amersham Pharmacia Biotech). Insulin mRNA bands were quantified by densitometry and recalculated per amount of $28 \mathrm{~S}$ rRNA, detected in each lane, using The Kodak Digital Science camera and Kodak Digital Science ID software (Eastman Kodak Company, Rochester, NY, USA).

\section{Electrophoretic Mobility Shift Assay} and Cross-Linking Analysis

The ins-PRS RNA oligonucleotide (Scandinavian Gene Synthesis AB, Köping, Sweden) (1 pmol), was incubated for $45 \mathrm{~min}$ at $37^{\circ} \mathrm{C}$ with $50 \mu \mathrm{Ci}\left[\gamma^{32} \mathrm{P}\right]$ ATP (5000 Ci/mmole, Amersham Pharmacia) and 8 units bacteriophage T4 polynucleotide kinase (SigmaAldrich). Heating for $2 \mathrm{~min}$ at $60^{\circ} \mathrm{C}$ then inactivated the kinase. The radiolabeled RNA-oligonucleotide was purified on Chroma spin-10 columns (Clontech Laboratories Inc., Paolo Alto, CA, USA). The integrity of the RNA oligonucleotide was controlled by electrophoresis in a $15 \%$ polyacrylamide gel. The RNA oligonucleotide was stored at $-20^{\circ} \mathrm{C}$ until use.

Rat islets in groups of 50 were incubated in normoxic or hypoxic $\left(1 \%\right.$ or $\left.5 \% \mathrm{O}_{2}\right)$ glucose-free RPMI-WS, containing $2.8 \mathrm{mM}$ glucose, with or without $50 \mu \mathrm{M}$ hydrogen peroxide or $2.5 \mathrm{mM}$ of the nitric oxide donor DETA NONOate (Alexis Biochemicals, San Diego, CA, USA) for $20 \mathrm{~min}$ or $\mathrm{l} \mathrm{hr}$ at $37^{\circ} \mathrm{C}$. After incubation, the islets were collected and washed in ice-cold PBS. Following centrifugation the cells were homogenized in $50 \mu \mathrm{l}$ homogenization buffer (10 $\mathrm{mM}$ HEPES, $5 \mathrm{mM}$ $\mathrm{MgCl}_{2}, 50 \mathrm{mM} \mathrm{KCl}, 10 \%$ glycerol, and $1 \mathrm{mM}$ phenylmethylsulfonyl fluoride [PMSF]) (24) by using a Pellet Pestle Motor (Kontes, Scientific Glassware/Instruments, Vineland, NJ, USA). The homogenates were centrifuged at 13,000 $\mathrm{g}$ for $10 \mathrm{~min}$ at $4^{\circ} \mathrm{C}$. The supernatant was used in the 
electrophoretic mobility shift assay. Nitrite accumulation was measured in the medium at the end of the incubation time, as an indicator of nitric oxide release from the nitric oxide donor. Ten microliters of freshly made Griess reagent was added to $100 \mu \mathrm{l}$ of medium (26). The samples were incubated at room temperature for $20 \mathrm{~min}$, after preincubating at $60^{\circ} \mathrm{C}$ for $2 \mathrm{~min}$, and the absorbance was measured at $546 \mathrm{~nm}$ on a Beckman DU-62 spectrophotometer (Palo Alto, CA, USA).

The RNA-protein binding reaction was performed as described (1). Duplicates containing $20 \mu \mathrm{l}$ homogenate, $200 \mathrm{ng} / \mathrm{ml}$ Escherichia coli tRNA, 10\% glycerol, and $1 \mu \mathrm{l}$ radiolabeled RNA-oligonucleotide probe $(40,000-100,000$ cpm/reaction) were prepared. To one of the duplicates $11 \mathrm{mM}$ DTT was added. The reaction mixtures were incubated at $30^{\circ} \mathrm{C}$ for $30 \mathrm{~min}$. RNase Tl (20 units/sample) was added and the incubation proceeded for $10 \mathrm{~min}$ at $30^{\circ} \mathrm{C}$. Finally the samples were incubated another $10 \mathrm{~min}$ with $5 \mathrm{mg} / \mathrm{ml}$ heparin. In some cases, the reaction mixtures were divided into two aliquots, one that was cross-linked by exposure to UV radiation $(260 \mathrm{~nm})$ for $10 \mathrm{~min}$ and then analyzed by boiling the samples in SDS-sample buffer without beta-mercaptoethanol and separated on a $9 \%$ SDS-PAGE gel for $\mathrm{l} \mathrm{hr}$ at $160 \mathrm{~V}$. The other aliquot was used directly for nondenaturing gel electrophoresis. In the latter case, the samples were applied on a $7 \%$ polyacrylamide gel and electrophoresed in $0.5 \times \mathrm{TBE}$ at $100 \mathrm{~V}$ for $\mathrm{l} \mathrm{hr}$. The free probe was run out of the gel to avoid radioactive contamination when analyzing the ins-PRS-protein complexes. The gel was fixed $(30 \%$ ethanol, $10 \%$ acetic acid), dried and exposed to a film overnight at $-70^{\circ} \mathrm{C}$. The results were analyzed by the Kodak system.

\section{Western Hybridization}

Islets in groups of 35 were incubated at normoxia or hypoxia $\left(5 \% \mathrm{O}_{2}\right)$ for $1 \mathrm{hr}$. The islets were thoroughly rinsed in ice-cold PBS before they were dissolved in SDS-sample buffer. The proteins were separated on a $12 \%$ SDS-PAGE and blotted on a nitrocellulose filter. The filters were hybridized with the monoclonal anti-PTB 3 antibody (27). Horseradish peroxidase conjugated anti-mouse antibody (1:1000) was used as secondary antibody, which was detected by the Amersham ECL system (Amersham Pharmacia).

\section{Lipofection of Islet Cells with ins-PRS Reporter Gene Vectors}

Double-stranded DNA oligonucleotides with the sequences of wild-type (wt) ins-PRS or mutant insPRS (Table 1) were cloned in to the $\mathrm{pCR}^{\mathrm{TM}_{3}-\mathrm{CAT}}$ vector (Invitrogen, San Diego, CA, USA) downstream of the coding sequence of the chloramphenicol acetyltransferase (CAT) reporter gene and upstream of the bovine growth hormone polyadenylation signal, as previously described (1). The cells were transfected with $1 \mu \mathrm{g}$ of either empty $\mathrm{pCR}^{\mathrm{TM}}{ }_{3-}$ CAT vector, $\mathrm{pCR}^{\mathrm{TM}} 3-\mathrm{CAT}+$ wild-type ins-PRS,

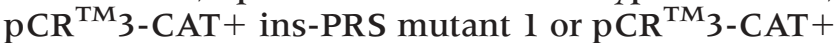
ins-PRS mutant 2 . The cells were then resuspended in $5 \mathrm{ml}$ RPMI-WS and maintained in culture for $48 \mathrm{hr}$ at $37^{\circ} \mathrm{C}$. The cells from each of the four dishes were then further cultured at $37^{\circ} \mathrm{C}$ for $24 \mathrm{hr}$ at normoxia or hypoxia $\left(5 \% \mathrm{O}_{2}\right)$ in $5 \mathrm{ml}$ RPMI-WS containing $2.8 \mathrm{mM}$ glucose. In some experiments, the culture medium was also supplemented with $5 \mu \mathrm{g} / \mathrm{ml}$ actinomycin D.

\section{Quantification of CAT Reporter Gene Expression by Semiquantitative RT-PCR}

The cells were collected from the previous step and the RNA was isolated using the Ultraspec Total RNA Isolation reagent. The RNA was dissolved in 30-32 $\mu \mathrm{l}$ RNase-free water. Thirty microliters of the RNA and $1 \mu \mathrm{M}$ oligo (dT)-primer were used for cDNA synthesis, in agreement with the You-Prime First-strand Beads protocol (Amersham Pharmacia). The samples were incubated at $37^{\circ} \mathrm{C}$ for $1 \mathrm{hr}$ followed by $65^{\circ} \mathrm{C}$ for 10 min. Some RNA samples were not used for cDNA synthesis but were analyzed in parallel by PCR to

Table 1. The sequences of the different ins-PRS probes used and comparison to the TH 3'-UTR. Ins-PRS, insulin pyrimidine-rich sequence; TH HIPBS, tyrosine hydroxylase hypoxia inducible protein binding sequence. The core binding sequences for respective mRNA are marked in bold and mutated nucleotides are underlined.

\begin{tabular}{ll}
\hline mRNA probe & \multicolumn{1}{c}{ Sequence } \\
\hline TH HIPBS & 5'CUUUCCCAAAGUCUCCAUCCCCUUCUCCAACCUUUCCU \\
Ins-PRS wild-type & 5'UCCACCACUCCCCGCCCACCCCUCU \\
Ins-PRS mutant 1 & 5'UCCACCACUCCCCGCCCACC 1 ACUCU \\
Ins-PRS mutant 2 & 5'UCCACCACUCCCCUCCCACCCCUCU
\end{tabular}

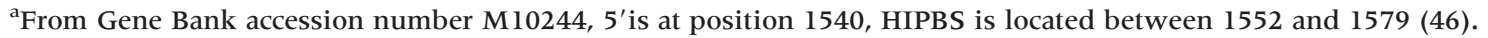

${ }^{\mathrm{b}}$ From Gene Bank accession number J00747, 5' is at position 4516.
} 
exclude the possibility of DNA contamination. The Touch Down Temperature cycling system (Hybaid, Teddlington, UK) was used for PCR. The sequences of the PCR primers (Cybergene AB, Huddinge, Sweden) were as follows:

\section{CAT forward: 5'GAATGCTCATCCGGAACT}

CAT reverse: 5'CCAGGGTCAAGGAAGGCACGG GAPDH forward: 5'GACCCCTTCATTGACCTCA GAPDH reverse: 5'CCTTCTCCATGGTGGTGAA $\beta$-actin forward: 5'CCTGCTTGCTGATCCACATCTGCTGG

$\beta$-actin reverse: 5'CTGACCGAGCGTGGCTAC

For amplification of samples incubated without actinomycin $\mathrm{D}$, the following time course was used: $94^{\circ} \mathrm{C}, 9 \mathrm{~min}$ and 25 cycles $94^{\circ} \mathrm{C}, 30 \mathrm{sec}, 55^{\circ} \mathrm{C}$, $45 \mathrm{sec}$ and $72^{\circ} \mathrm{C}, 90 \mathrm{sec}$ (CAT and $\beta$-actin). When analyzing samples incubated in the presence of actinomycin D: $94^{\circ} \mathrm{C}, 9 \mathrm{~min}$ and 30 cycles (GAPDH) of $94^{\circ} \mathrm{C}, 45 \mathrm{sec}, 55^{\circ} \mathrm{C}, 45 \mathrm{sec}$ and $72^{\circ} \mathrm{C}, 1 \mathrm{~min}$ or 30 cycles $\left(\beta\right.$-actin) $94^{\circ} \mathrm{C}, 30 \mathrm{sec}, 55^{\circ} \mathrm{C}, 30 \mathrm{sec}$ and $72^{\circ} \mathrm{C}, 90 \mathrm{sec}$ were used. The PCR products were run in a $1.5 \%$ agarose gel and stained with ethidium bromide for quantification using the Kodak system. CAT mRNA was normalized against $\beta$-actin or GAPDH.

\section{Statistics}

Means \pm SEM were calculated and the Student paired $t$-test was performed. When analyzing the insulin mRNA levels one-way ANOVA for repeated measurements and Dunnet's test was used.

\section{Results \\ Verification of Culture Medium Oxygen Tension}

Normal oxygen tension, $150 \mathrm{~mm} \mathrm{Hg}$, was set as $100 \%$. After 10 min of gassing with $5 \% \quad \mathrm{O}_{2} / 5 \%$ $\mathrm{CO}_{2} / 85 \% \mathrm{~N}_{2}$ the oxygen tension in the media of three separate flasks were $30.3 \pm 0.57$, which gives an oxygen tension of approximately $45.5 \mathrm{~mm} \mathrm{Hg}$. After 20 or $30 \mathrm{~min}$ of gassing the tension was $25.8 \pm$ $1.80 \%(38.8 \mathrm{~mm} \mathrm{Hg})$ or $25.0 \pm 3.6 \%(37.5 \mathrm{~mm} \mathrm{Hg})$, respectively. Because $37.5 \mathrm{~mm} \mathrm{Hg}$ corresponds to $5 \% \mathrm{O}_{2}, 20-30 \mathrm{~min}$ of gassing was used in all experiments.

\section{Islet Cell Viability in Response to Hypoxia}

Islets cell death in response to incubation at different hypoxic conditions for $24 \mathrm{hr}$ was determined by vital staining with Hoechst 33342 and propidium iodide. This method allows the discrimination between necrosis and apoptosis in intact islets $(23,24)$. Inspection of the islets in a fluorescence microscope revealed a moderate increase in propidium iodide positive islet cells, mainly located centrally, in islets incubated at $5 \%$ oxygen (Fig. 1). Only small- to medium-sized islets were analyzed because large islets are known to develop central necrosis in tissue culture. At $1 \%$ oxygen, the increase in propidium iodide positive cells was more pronounced (Fig. 1). We did not observe any increase in apoptotic cells (i.e., propidium iodide negative cells with increased Hoechst staining and a nuclear morphology typical for apoptosis). The number of cells that had taken up propidium iodide where quantified by flow cytometric analysis. The percentage of propidium iodide

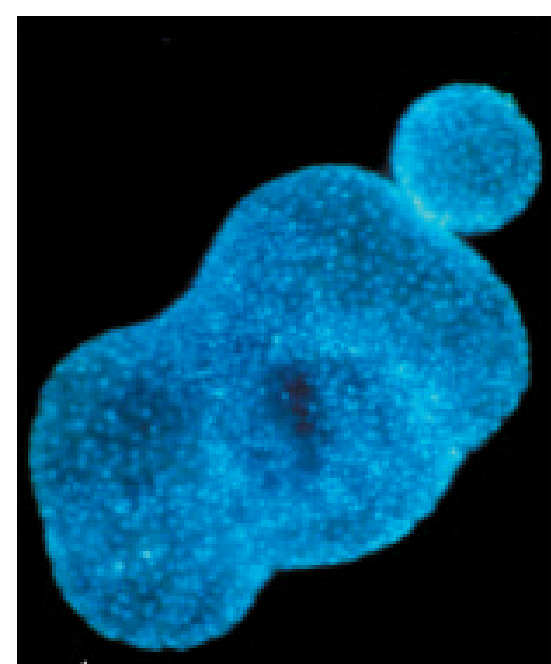

A

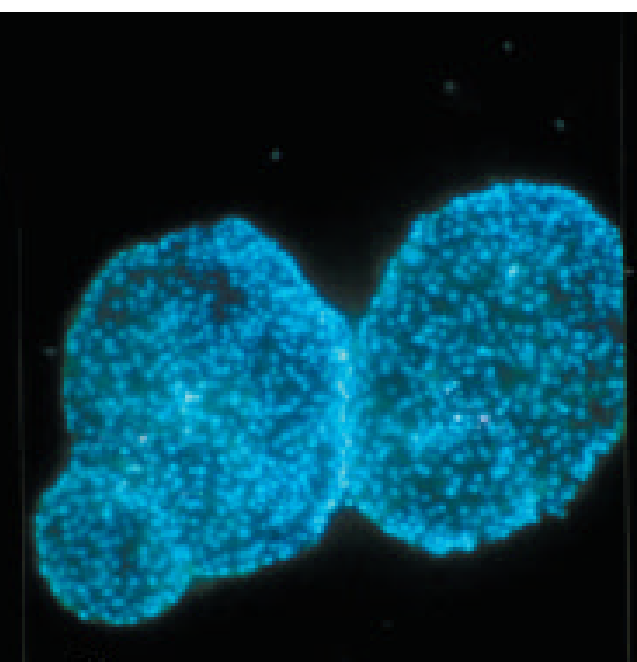

B

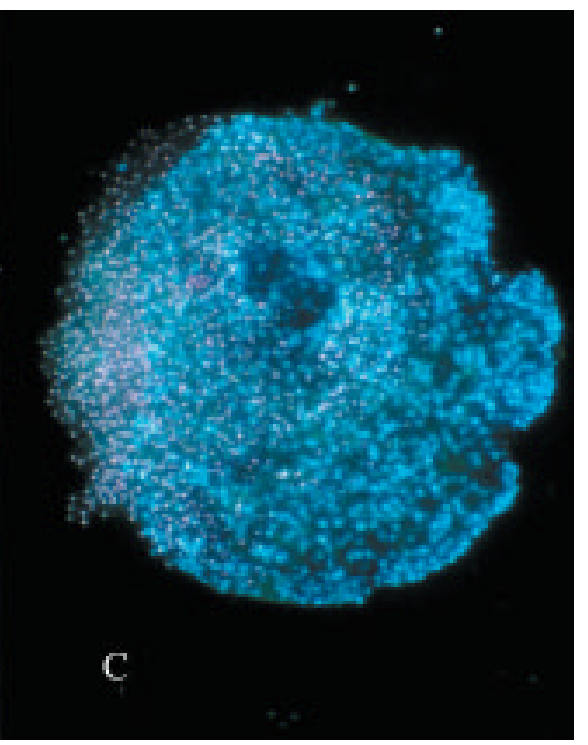

Fig. 1. Islet cell viability after 24-hr culturing at different media oxygen concentrations. Islets were incubated for 24 hr at declining oxygen concentrations: (A) $21 \% \mathrm{O}_{2} ;$ (B) $5 \% \mathrm{O}_{2}$; and (C) $1 \% \mathrm{O}_{2}$. Cell viability was determined by staining with Hoechst 33342 and propidium iodide, followed by fluorescence microscopy. The nuclei of viable cells are blue, nuclei with pink fluorescence represent necrotic cells, and the nuclei of apoptotic cells should be condensed and fragmented and appear light blue or even white (not seen in this picture, 23). 
positive cells from islets incubated at different oxygen levels were in three separate experiments: $1.4 \pm$ $0.7 \%, 2.9 \pm 0.8 \%, 4.4 \pm 2.3 \%$, and $10.1 \pm 3.7 \%$ at $21 \%, 10 \%, 5 \%$ and $1 \%$ oxygen, respectively. Because prolonged exposure to pronounced hypoxia $\left(1 \% \mathrm{O}_{2}\right)$ increased beta cell death, primary by accelerating necrosis (Fig. 1), we chose to expose islets to only mild hypoxia $\left(10 \%\right.$ and $\left.5 \% \mathrm{O}_{2}\right)$ and to limit the exposure period to 6 and $16 \mathrm{hr}$ in most experimental setups. However, we cannot exclude that there exists some degree of heterogeneity in the islet population, and that a fraction of the islet cells may have become severely anoxic even though the oxygen concentration of the surrounding culturing media was as high as $\mathbf{5 \%}$.

\section{Hypoxia Increases Rat Islet Insulin mRNA Levels}

It was observed that exposure to $5 \%$ of $\mathrm{O}_{2}$ in the presence of $2.8 \mathrm{mM}$ glucose increased insulin mRNA levels by $33 \%$ at $6 \mathrm{hr}$ and by $100 \%$ at $16 \mathrm{hr}$ (Fig. 2A). A high glucose concentration $(28 \mathrm{mM})$ increased insulin mRNA to a similar extent as that observed in response to hypoxia (Fig. 2A). There were no additive effects of glucose $(28 \mathrm{mM})$ and hypoxia $(10 \%)$ (Fig. 2A). In the presence of actinomycin D, there was no stimulatory effect of hypoxia or $28 \mathrm{mM}$ glucose on insulin mRNA levels (Fig. 2B).

Hypoxia Increases Binding of the PTB to the ins-PRS, but not РТВ Expression

Because glucose and reducing agents stimulate insPRS binding activity in vivo and in vitro, respectively (1), and because it is known that both glucose and acute hypoxia promote an increased redox potential in islet cells $(28,29)$, we next analyzed insPRS binding activity in hypoxia-treated islets. Cross-linking experiments showed that DTT and hypoxia (Fig. 3A) increased formation of a $65-\mathrm{kDa}$ complex, which is at the same position as the glucoseinduced complex (1). The ins-PRS binding protein was previously identified as PTB (1). Binding of PTB to ins-PRS was equally increased in response to hypoxia as to DTT (Fig. 3B). Its hypoxia-induced binding activity is probably mediated through posttranslational modifications; hypoxia $\left(5 \% \mathrm{O}_{2}\right)$ had no effect on PTB protein expression after l-hr incubation (data not shown).

Hypoxia-Increased ins-PRS Binding Activity is Counteracted by Hydrogen Peroxide, but not by Nitric Oxide

We next studied whether the oxidizing agent hydrogen peroxide or a nitric oxide donor, DETA NONOate, could affect alterations in binding activity. The islets were incubated for $20 \mathrm{~min}$ at $1 \% \mathrm{O}_{2}$ and at a substimulatory glucose concentration. This resulted in increased ins-PRS-binding activity at nonreducing conditions (Fig. $4 \mathrm{~A}$ and $4 \mathrm{~B}$, lane 3 versus lane 1). The hypoxia-induced increase in insPRS-binding activity was counteracted by the addition of $50 \mu \mathrm{M}$ hydrogen peroxide, but was not

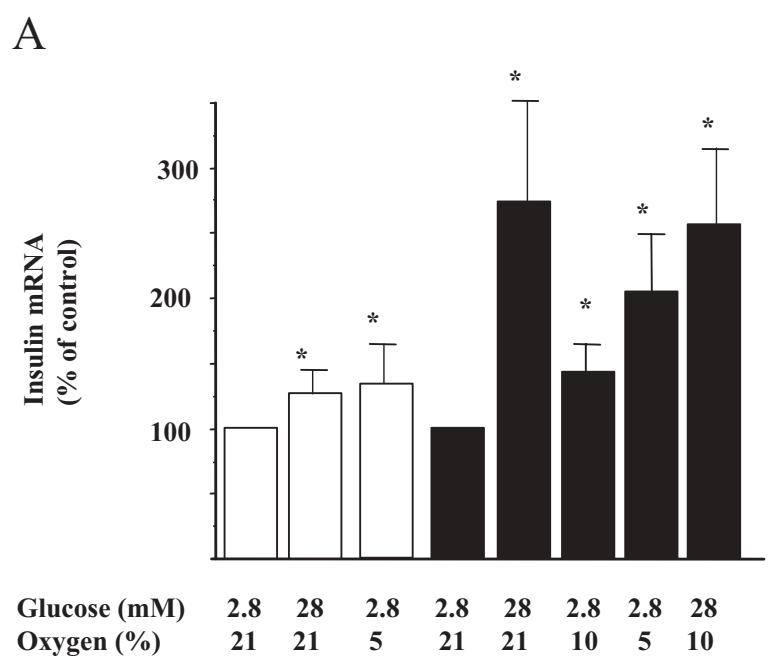

B

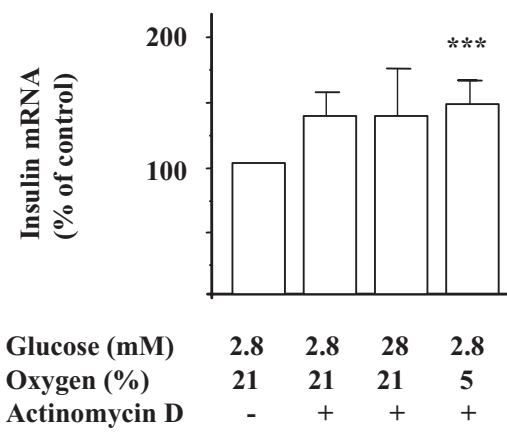

Fig. 2. Hypoxia increases insulin mRNA levels in isolated rat islets. Isolated rat islets were incubated for $6 \mathrm{hr}$ (white bars) or $16 \mathrm{hr}$ (black bars) in the presence of normoxia $\left(21 \% \mathrm{O}_{2}\right)$ or hypoxia $\left(10 \%\right.$ or $\left.5 \% \mathrm{O}_{2}\right)$ at 2.8 or $28 \mathrm{mM}$ glucose, without (A) or with (B) $5 \mu \mathrm{g} / \mathrm{ml}$ actinomycin D. Insulin mRNA was detected by Northern hybridization and expressed per $28 \mathrm{~S}$ rRNA and shown as percentage of control. Results are means \pm SEM for six observations. ${ }^{*} p<0.05 ;{ }^{* * *} p<0.005$ versus control using one-way ANOVA for repeated measurements and Dunnet's test.

changed by the presence of $2.5 \mathrm{mM}$ of the nitric oxide donor DETA NONOate (Fig. 4A). These results indicate that reactive oxygen species and/or the redox potential regulate ins-PRS binding.

\section{Inhibition of PTB Binding to ins-PRS Results in $m R N A$ Destabilization}

To assess whether hypoxia regulates insulin mRNA stability by controlling PTB binding to ins-PRS in vivo, we lipofected dispersed rat islet cells with $\mathrm{pCR}^{\mathrm{TM}}$-CAT vector with or without wild-type or mutated ins-PRS, as described previously (1). Two days following the transfection, the cells were exposed for $24 \mathrm{hr}$ to normoxic or hypoxic $\left(5 \% \mathrm{O}_{2}\right)$ conditions at substimulatory glucose concentrations with or without actinomycin D. Similar results 
A
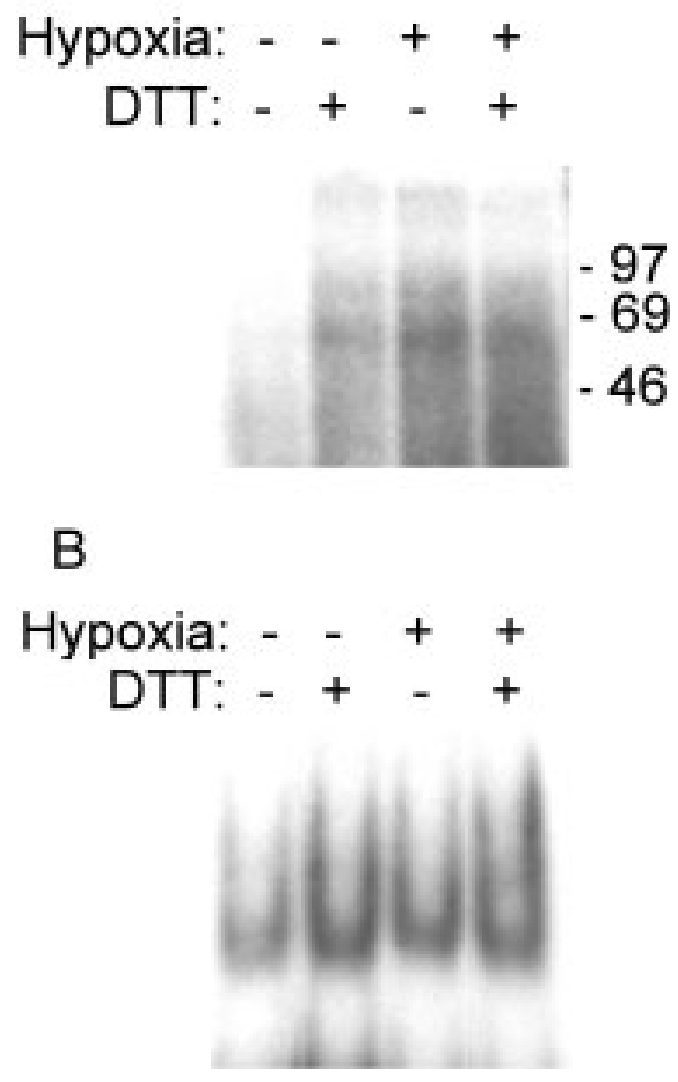

Fig. 3. Hypoxia increases ins-PRS-protein binding activity. The ${ }^{32} \mathrm{P}$-labelled insulin mRNA-oligonucleotide, ins-PRS, was incubated with rat islet extract, from islets incubated for $1 \mathrm{hr}$ in normoxic or hypoxic $\left(5 \% \mathrm{O}_{2}\right) 2.8 \mathrm{mM}$ glucose-containing medium. The reactions were performed with $(11 \mathrm{mM})$ or without DTT. In (A), the samples were cross-linked by exposure to UV radiation $(260 \mathrm{~nm})$ for $10 \mathrm{~min}$ and then analyzed by boiling in SDS-sample buffer without beta-mercaptoethanol and separation on a SDS-PAGE gel for $1 \mathrm{hr}$ at $160 \mathrm{~V}$. In (B), the samples were directly separated with nondenaturating polyacrylamide gel electrophoresis. Results shown are representative for three separate observations.

where obtained both with (Fig. 5B) and without actinomycin D (Fig. 5A), indicating that transcription was not affected by the ins-PRS mutation. We observed that the reporter gene mRNA containing the wild-type rat insulin I ins-PRS was equally abundant as the mRNA lacking ins-PRS (Fig. 5). However, a mutation of one of the critical pyrimidines to a purine in the ins-PRS core-binding site resulted in a marked destabilization of the mRNA, whereas a mutation of a purine to a pyrimidine outside the core-binding site had little effect (Fig. 5). As expected, hypoxia did not affect reporter mRNA levels in cells transfected with pCR $3^{\mathrm{TM}}$-CAT lacking wild-type or mutated ins-PRS. In cells transfected with wild-type ins-PRS-pCR $3^{\mathrm{TM}}$-CAT, however, there was a nonsignificant trend to higher reporter mRNA levels in response to hypoxia, in the absent
A

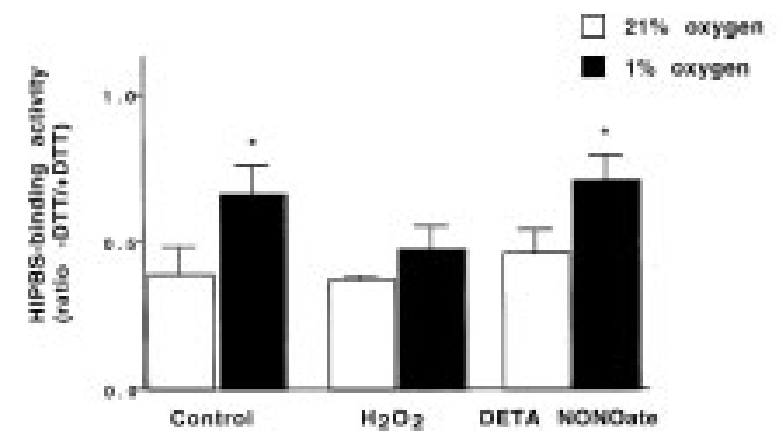

B

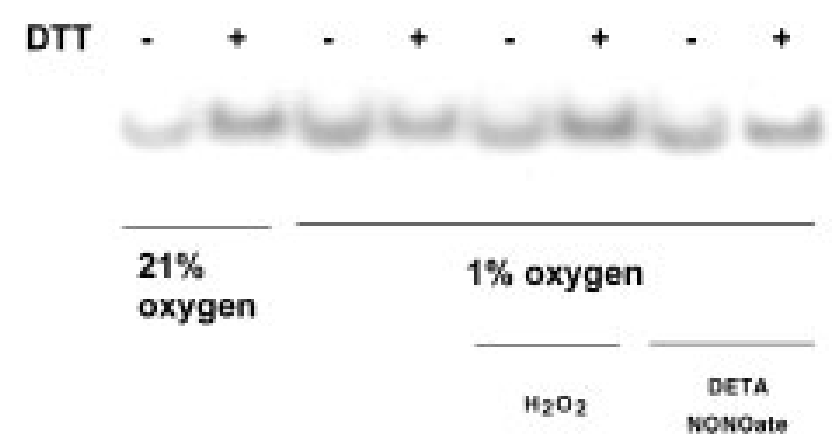

Fig. 4. Hypoxia-induced increase in ins-PRS-protein binding activity is counteracted by hydrogen peroxide but not affected by nitric oxide. The binding activity was measured by EMSA. The ${ }^{32} \mathrm{P}$-labelled insulin mRNA-probe, ins-PRS, was incubated with rat islets extract, from islets incubated for $20 \mathrm{~min}$ in normoxic or hypoxic $\left(1 \% \mathrm{O}_{2}\right) 2.8 \mathrm{mM}$ glucose medium, with or without hydrogen peroxide $(50 \mu \mathrm{M})$ or the nitric oxide donor DETA NONOate $(2.5 \mathrm{mM})$. The reactions were performed with $(11 \mathrm{mM})$ or without DTT and separated with nondenaturating polyacrylamide gel electrophoresis. (A) Ins-PRS binding activity during each condition was expressed as ratio between the shifted ins-PRS-protein complex without and with DTT. Results are mean \pm SEM for six observations. Results were compared by Student paired $\boldsymbol{t}$-test. ${ }^{*} p<0.05$ when comparing versus corresponding control. (B) Representative autoradiograph showing EMSA analysis of ins-PRS binding activity. The white control bar in Figure 3A represents the ratio between lanes 1 and 2 in Figure $3 \mathrm{~B}$, and the black control bar represents the ratio between lanes 3 and 4 in Figure 3B, and so forth.

of actinomycin D. Nevertheless, this suggests that ins-PRS alone is not sufficient to confer hypoxia mediated mRNA stabilization, which is in line with our previous results showing the same for glucose-regulated mRNA stability (1).

\section{Discussion}

We currently observe that hypoxia increases insulin mRNA levels in beta cells. In the presence of actinomycin D there were no effects of hypoxia on insulin mRNA levels. This could possibly be explained by the previous finding that an actinomycin 

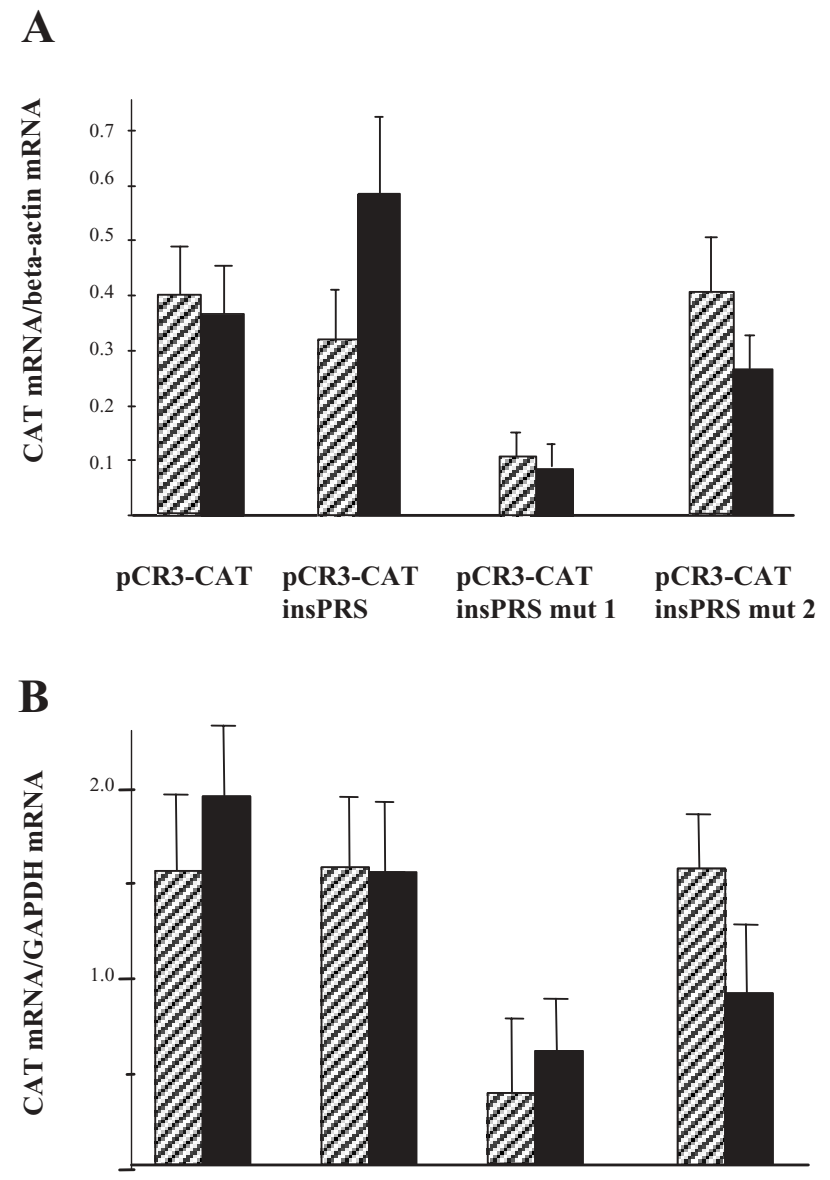

$\begin{array}{llll}\text { pCR3-CAT } & \begin{array}{l}\text { pCR3-CAT } \\ \text { insPRS }\end{array} & \begin{array}{l}\text { pCR3-CAT } \\ \text { insPRS mut } 1\end{array} & \begin{array}{l}\text { pCR3-CAT } \\ \text { insPRS mut } 2\end{array}\end{array}$

Fig. 5. Mutation of the ins-PRS leads to reporter CAT mRNA destabilization. Rat islets cells were transfected with four different constructs. The empty $\mathrm{pCR}^{\mathrm{TM}} 3$-CAT vector, the $\mathrm{pCR}^{\mathrm{TM}} 3$-CAT vector with wild-type, mutant 1 , or mutant 2 ins-PRS inserted in the 3'-UTR of the vector. Two days after the transfection, the islets were incubated for $24 \mathrm{~h}$ in $2.8 \mathrm{mM}$ glucose during normoxic (hatched bars $=21 \% \mathrm{O}_{2}$ ) or hypoxic (black bars $=5 \% \mathrm{O}_{2}$ ) conditions, without $(\mathrm{A})$ or with (B) $5 \mu \mathrm{g} / \mathrm{ml}$ actinomycin D. RT-PCR was performed for CAT, $\beta$-actin, and GAPDH mRNA. Results are mean \pm SEM for three to four experiments.

D-induced inhibition of transcription of RNA degrading factors results in insulin mRNA stabilization (2), which could have masked the hypoxiainduced effects. Hypoxia-induced stabilization of VEGF-mRNA is known to occur in the presence of actinomycin D, indicating that activation of transcription is not necessary for this particular event (29). Similar experiments cannot easily be performed when studying insulin mRNA in islets tissue for two reasons. First, it is difficult to obtain large amounts of islets, which are required for such time course studies. Second, the long half-life of insulin mRNA, 29-77 hr (2), implies that the time course must be extended over several days to detect a decrease in insulin mRNA. Unfortunately, culture of islets for several days in the presence of transcription inhibitors affects the islets cell viability negatively. Thus, we cannot exclude that the increase in insulin mRNA by a 16-hr exposure to hypoxia involves transcriptional effects.

Our previous findings that glucose-induced changes in insulin mRNA stability have a major impact on insulin mRNA levels and that glucose promoted binding of PTB to the insulin mRNA 3'-UTR (1) prompted us to next investigate whether this mRNA-protein interaction is stimulated also by hypoxia. Indeed, the hypoxia-induced increase in insulin mRNA levels was accompanied by increased binding of PTB to the pyrimidine-rich sequence of the insulin 3'-UTR, which we refer to as the insPRS. Further, mutation of the core PTB-binding site resulted in dramatic drop in reporter gene mRNA expression, at both normoxia and hypoxia. Introduction of the wild-type ins-PRS did not significantly affect the reporter gene mRNA expression. These results are in line with our previous findings on glucose-induced ins-PRS-PTB binding (1). As we concluded then, the ins-PRS-PTB binding is probably not sufficient, but indispensable, for constitutive as well as regulated insulin mRNA stability. Therefore, it is likely that additional proteins and mRNA regions need to interact to obtain full regulation of mRNA stability.

Despite recent advances, the details of the mammalian oxygen sensor system remain largely unknown. Hypoxia probably activates several intracellular signaling pathways (30-33), of which one may involve changes in the intracellular redox potential. The activity of hypoxia-inducible factor 1 (HIF-1), a transcription factor that is critical for hypoxic induction of a number of physiologically important genes, is enhanced in response to an increased redox potential of the cell (34). Thus, it is conceivable that the insulin-producing cell utilizes changes in the redox potential to mediate the hypoxia-induced effects upon mRNA stability and transcription. Indeed, it is well established that glucose increases the redox potential of insulin-producing cells (28). Moreover, moderate hypoxia is known to increase the redox potential mainly due to a lowered production of reactive oxygen radicals and a decreased oxidation of $\mathrm{NADH}$ in islets mitochondria (29). In our system, the hypoxia-activated PTB binding to ins-PRS was inhibited by exogenous hydrogen peroxide. Induction of hypoxia-induced genes is in other systems inhibited by hydrogen peroxide, and a pharmacologically achieved decrease of endogenous hydrogen peroxide levels is known to induce TH and EPO mRNA (reviewed in 30,32). Thus, hydrogen peroxide has been proposed to serve as an intracellular signaling molecule sensitive to changes in oxygen pressure $(30,32,33)$. The details are not clear, but cytochrome b might have an activating effect on a 
particular $\mathrm{NAD}(\mathrm{P}) \mathrm{H}$ oxidase, which as a consequence generates hydrogen peroxide in an oxygendependent manner. By this mechanism, hypoxia would result in declining levels of hydrogen peroxide, leading to a shift toward a more reduced state $(30,33)$. The lack of hydrogen peroxide may affect the phosphorylation of proteins and/or shift protein thiols to reduced forms, thereby stimulating the HIF-1 nucleic acid binding capacity (30) and other cellular functions that respond to hypoxia.

Given the similarities between nitric oxide and oxygen (they both bind to ferrous atoms in heme proteins), it is possible that nitric oxide could either mimic or inhibit hypoxia-induced signals. Nitric oxide has in fact been demonstrated to inhibit hypoxia-induced TH (35), erythropoietin (EPO) $(36,37)$ and VEGF $(38)$ gene transcription and to decrease TH mRNA stability (35). This effect is probably achieved by a nitric oxide-mediated inhibition of the HIF-1 DNA-binding activity $(35,39)$. HIF- 1 also regulates nitric oxide synthase (NOS) gene transcription and high levels of nitric oxide may in some tissues exert a negative feedback on inducible NOS gene expression via HIF-1 regulation (33). Nitric oxide can probably interfere with hypoxia signaling pathways in other ways than binding heme proteins. Indeed, a short-time exposure to nitric oxide has been shown to inhibit the formation of reactive oxygen species $(40)$. Nitric oxide may inhibit cytochrome oxidase activity by competing with oxygen, leading to a decreased production of reactive oxygen species (31). Because hydrogen peroxide often prevents a hypoxic response, it could in this context be anticipated that nitric oxide mimics hypoxia. Indeed, nitric oxide has also been reported to enhance $c$-fos, EPO (35), and VEGF (41) mRNA expression. These contradictory roles of nitric oxide could possibly be explained by tissue-, dose-, and time-related factors. In the present study, however, we could not detect any significant effects on PTBins-PRS binding by the nitric oxide donor DETA NONOate. Because only acute effects of nitric oxide were presently assessed, the possibility remains that nitric oxide might alter ins-PRS-PTB interactions over a longer time period. This notion fits well with recent findings showing increased PTB expression in rat islets exposed for $\mathbf{2 4} \mathrm{hr}$ to nitric oxide-inducing cytokines or chemically derived nitric oxide (14).

The physiologic role of insulin during hypoxia is unclear. On the one hand, it is known that exercise-induced hypoxia is associated with decreased insulin release, hypoglycemia, and increased insulin-independent glucose uptake (42). In this situation, increased insulin production would clearly not be beneficial. On the other hand, high altitudeassociated hypoxia in humans results in hyperinsulinemia and hyperglycemia, which is probably due to an impaired insulin action (43). Similar results were shown in newborn calves breathing hypoxic gas for $2 \mathrm{hr}$. In this study, it was concluded that blood glucose and plasma insulin were increased due to insulin resistance (44). Furthermore, in fasting rats exposed to hypoxia for $48 \mathrm{hr}$, plasma glucose and insulin concentrations were significantly increased (45). Thus, increased insulin release may be an appropriate response in certain hypoxic situations that are associated with decreased insulin sensitivity.

It is also unclear whether the presently observed hypoxia-induced increase in insulin mRNA levels results in an increased release in insulin. The general opinion seems to be that severe hypoxia and the subsequent reduction of intracellular ATP/ADP ratio is restraining the ATP demanding secretion of insulin (46-50). Several studies have shown that the first phase of insulin secretion often remains intact while the second phase of secretion declines. At what oxygen tension this occurs depends on whether whole islets or single cells are studied. Islets are affected at oxygen tension below $60-30 \mathrm{~mm}$ $\mathrm{Hg}(48,49,51)$, whereas single cells from primary islets or $\beta$ cell lines are containing normal second phase secretion at oxygen levels above 7-12 $\mathrm{mm} \mathrm{Hg}$ $(52,53)$. Further investigations will hopefully establish at which hypoxic conditions, if any, increased

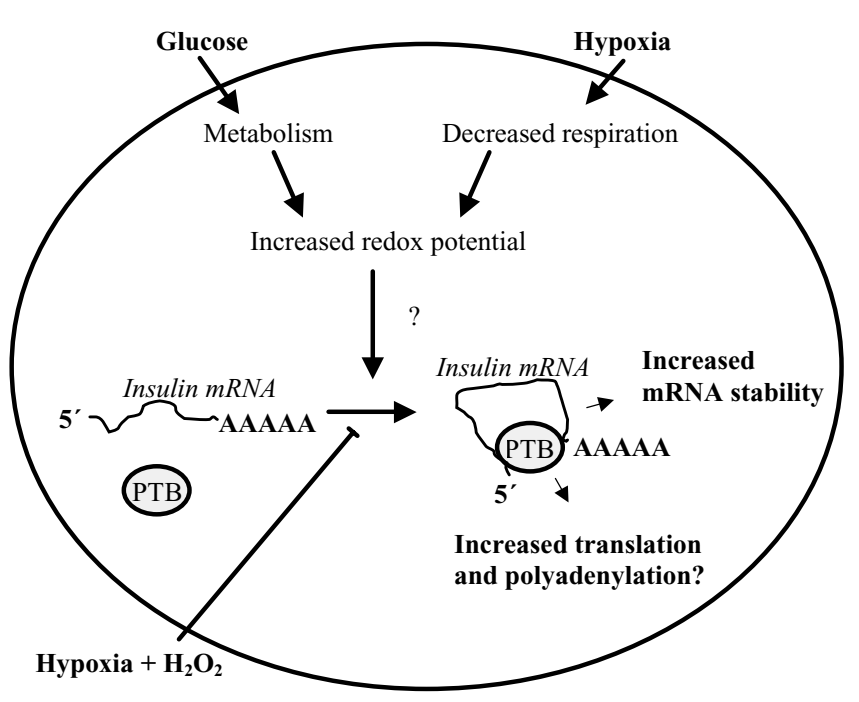

Fig. 6. Drawing showing the putative role of PTB in the regulation of insulin mRNA stability. We hypothesize that glucose and hypoxia increase binding of PTB to the pyrimidinerich sequence in ins-PRS by their ability to increase the redox potential of the $\beta$ cell. Interaction between PTB and the insPRS leads to an increased stability of the mRNA. Because PTB has been shown, in other systems, to participate in both translation and polyadenylation processes, it is possible that PTB might act by forming a loop of the insulin mRNA. Circularization of RNA is known to promote both higher messenger stability, as well as a more efficient translation. So far the hypoxia signaling pathways leading to increase ins-PRS-PTB binding are unknown. Because exogenous addition of hydrogen peroxide $\left(\mathrm{H}_{2} \mathrm{O}_{2}\right)$ decreased the hypoxia-induced ins-PRS-PTB interaction, it is possible that the changes of the redox potential and/or reactive oxygen species mediate the hypoxia- and glucose-induced signals. 
insulin mRNA levels results in an increased release of insulin. In this context, it could be speculated that hypoxia-induced insulin mRNA stabilization is of minor physiologic importance and that the $\beta$ cell instead utilizes a phylogenetically older signaling system to achieve glucose-regulated insulin gene expression.

We have previously identified an interaction between the rat insulin I 3'-UTR and the protein PTB. This binding seems to be involved in regulation of insulin mRNA stability, and can be enhanced by glucose and reducing compounds (1). We show here that hypoxia increases insulin mRNA levels in $\beta$-cells in vitro. In addition, PTB binding to the insPRS was stimulated in parallel, and we conclude that this latter event is necessary, but not sufficient, for maintained mRNA stability. Finally, the hypoxiainduced PTB and ins-PRS interaction was prevented by hydrogen peroxide, implicating the involvement of reactive oxygen species and the importance of the redox status for regulated PTB binding (Fig. 6). Future studies using nonrodent islets will hopefully clarify whether hypoxia-induced stabilization of insulin mRNA is a rodent-specific phenomenon. In addition, it should also be determined whether the (rodent) insulin-producing cell promotes glucoseinduced stabilization of insulin mRNA by at least in part the same mechanisms as those induced by hypoxia and through which signaling pathways this is mediated.

\section{Acknowledgments}

The excellent technical assistance of Ing-Marie Mörsare and Ing-Britt Hallgren is gratefully acknowledged. We also thank Per-Ola Carlsson for performing the oxygen tension measurements and David Helfman and colleagues for the generous PTB antibody gift.

This work was supported by grants from the Swedish Medical Research Council (12X-109, 12X11564, 72P-12995), the Swedish Diabetes Association, the Nordic Insulin Fund, the Juvenile Diabetes Foundation International, and the Family Ernfors Fund.

\section{References}

1. Tillmar L, Carlsson C, Welsh N. (2002) Control of insulin mRNA stability in rat pancreatic islets: regulatory role of a 3'UTR pyrimidine-rich sequence. J. Biol. Chem. 277: 1099-1106.

2. Welsh M, Nielsen DA, MacKrell AJ, Steiner DF. (1985) Control of insulin gene expression in pancreatic beta cells and in an insulin-producing cell line, RIN-5F cells. II. Regulation of insulin mRNA stability. J. Biol. Chem. 260: 13590-13594.

3. Wicksteed B, Herbert TP, Alarcon C, Lingohr MK, Moss LG, Rhodes CJ. (2001) Cooperativity between the preproinsulin mRNA untranslated regions is necessary for glucosestimulated translation. J. Biol. Chem. 276: 22553-22558.

4. Li HP, Huang P, Park S, Lai MM. (1999) Polypyrimidine tractbinding protein binds to the leader RNA of mouse hepatitis virus and serves as a regulator of viral transcription. J. Virol. 73: $772-777$.

5. Ashiya M, Grabowski PJ. (1997) A neuron-specific splicing switch mediated by an array of pre-mRNA repressor sites: evidence of a regulatory role for the polypyrimidine tract binding protein and a brain-specific PTB counterpart. RNA 3: 996-1015.

6. Markovtsov V, Nikolic JM, Goldman JA, Turck CW, Chou MY, Black DL. (2000) Cooperative assembly of an hnRNP complex induced by a tissue-specific homolog of polypyrimidine tract binding protein. Mol. Cell. Biol. 20: 7463-7479.

7. Sickinger S, Schweizer M. (1999) A high affinity binding site for the polypyrimidine tract binding protein (PTB) is located in the 5'-untranslated region of the rat proteinase alphalinhibitor 3 variant I gene. Biol. Chem. 380: 1217-1223.

8. Kim JH, Hahm B, Kim YK, Choi M, Jang SK. (2000) Proteinprotein interaction among hnRNPs shuttling between nucleus and cytoplasm. J. Mol. Biol. 298: 395-405.

9. Moreira A, Takagaki Y, Brackenridge S, Wollerton M, Manley JL, Proudfoot NJ. (1998) The upstream sequence element of the C2 complement poly(A) signal activates mRNA 3' end formation by two distinct mechanisms. Genes Dev. 12: 2522-2534.

10. Lou H, Helfman DM, Gagel RF, Berget SM. (1999) Polypyrimidine tract-binding protein positively regulates inclusion of an alternative 3 '-terminal exon. Mol. Cell. Biol. 19: 78-85.

11. Cote CA, Gautreau D, Denegre JM, Kress TL, Terry NA, Mowry KL. (1999) A Xenopus protein related to hnRNP I has a role in cytoplasmic RNA localization. Mol. Cell. 4: 431-437.

12. Wagner EJ, Garcia-Blanco MA. (2001) Polypyrimidine tract binding protein antagonizes exon definition. Mol. Cell. Biol. 21: 3281-3288.

13. Webb GC, Akbar MS, Zhao C, Steiner DF. (2000) Expression profiling of pancreatic beta cells: glucose regulation of secretory and metabolic pathway genes. Proc. Natl. Acad. Sci. U.S.A. 97: 5773-5778.

14. John NE, Andersen HU, Fey SJ, et al. (2000) Cytokine- or chemically derived nitric oxide alters the expression of proteins detected by two-dimensional gel electrophoresis in neonatal rat islets of Langerhans. Diabetes 49: 1819-1829.

15. Leffers H, Dejgaard K, Celis JE. (1995) Characterisation of two major cellular poly(rC)-binding human proteins, each containing three K-homologous (KH) domains. Eur. J. Biochem. 230: 447-453.

16. Makeyev AV, Liebhaber SA. (2000) Identification of two novel mammalian genes establishes a subfamily of $\mathrm{KH}-$ domain RNA-binding proteins. Genomics 67: 301-316.

17. Paulding WR, Czyzyk-Krzeska MF. (1999) Regulation of tyrosine hydroxylase mRNA stability by protein-binding, pyrimidine-rich sequence in the $3^{\prime}$-untranslated region. $J$. Biol. Chem. 274: 2532-2538.

18. Czyzyk-Krzeska MF, Bendixen AC. (1999) Identification of the poly $(\mathrm{C})$ binding protein in the complex associated with the $3^{\prime}$ untranslated region of erythropoietin messenger RNA. Blood 93: 2111-2120.

19. Yu J, Russell JE. (2001) Structural and functional analysis of an mRNP complex that mediates the high stability of human beta-globin mRNA. Mol. Cell. Biol. 21: 5879-5888.

20. Holcik M, Liebhaber SA. (1997) Four highly stable eukaryotic mRNAs assemble 3' untranslated region RNA- protein complexes sharing cis and trans components. Proc. Natl. Acad. Sci. U.S.A. 94: 2410-2414.

21. Andersson A. (1978) Isolated mouse pancreatic islets in culture: effects of serum and different culture media on the insulin production of the islets. Diabetologia 14: 397-404.

22. Carlsson PO, Palm F, Andersson A, Liss P. (12001) Markedly decreased oxygen tension in transplanted rat pancreatic islets irrespective of the implantation site. Diabetes 50: 489-495.

23. Saldeen J. (2000) Cytokines induce both necrosis and apoptosis via a common bcl-2- inhibitable pathway in rat insulinproducing cells. Endocrinology 141: 2003-2010.

24. Welsh, N. (2000) Assessment of apoptosis and necrosis in isolated islets of Langerhans: methodological considerations. Biochem. Res. 3: 189-200.

25. Chan SJ, Noyes BE, Agarwal KL, Steiner DF. (1979) Construction and selection of recombinant plasmids containing 
full-length complementary DNAs corresponding to rat insulins I and II. Proc. Natl. Acad. Sci. U.S.A. 76: 5036-5040.

26. Green LC, Wagner DA, Glogowski J, Skipper PL, Wishnok JS, Tannenbaum SR. (1982) Analysis of nitrate, nitrite, and [15N] nitrate in biological fluids. Anal. Biochem. 126: 131-138.

27. Grossman JS, Meyer MI, Wang YC, Mulligan GJ, Kobayashi R, Helfman DM. (1998) The use of antibodies to the polypyrimidine tract binding protein (PTB) to analyze the protein components that assemble on alternatively spliced pre-mRNAs that use distant branch points. RNA 4: 613-625.

28. Malaisse WJ, Malaisse-Lagae F, Sener A. (1984) Coupling factors in nutrient-induced insulin release. Experientia 40: 1035-1043.

28. Berne C, Brolin SE, Agren A. (1973) Influence of ischemia on the levels of reduced pyridine nucleotides in the pancreatic islets. Horm. Metab. Res. 5: 141-142.

29. Levy AP, Levy NS, Goldberg MA. (1996) Hypoxia-inducible protein binding to vascular endothelial growth factor mRNA and its modulation by the von Hippel-Lindau protein. J. Biol. Chem. 271: 25492-25497.

30. Czyzyk-Krzeska MF. (1997) Molecular aspects of oxygen sensing in physiological adaptation to hypoxia. Respir. Physiol. 110: 99-111.

31. Semenza GL. (1999) Perspectives on oxygen sensing. Cell 98: 281-284.

32. Wenger RH. (2000) Mammalian oxygen sensing, signaling and gene regulation. J. Exp. Biol. 203: 1253-1263.

33. Lopez-Barneo J, Pardal R, Ortega-Saenz P. (2001) Cellular mechanism of oxygen sensing. Annu. Rev. Physiol. 63: 259-287.

34. Huang LE, Arany Z, Livingston DM, Bunn HF. (1996) Activation of hypoxia-inducible transcription factor depends primarily upon redox-sensitive stabilization of its alpha subunit. J. Biol. Chem. 271: 32253-32259.

35. Adhikary G, Premkumar DR, Prabhakar NR. (2000) Dual influence of nitric oxide on gene regulation during hypoxia. Adv. Exp. Med. Biol. 475: 285-292.

36. Todorov V, Gess B, Godecke A, Wagner C, Schrader J, Kurtz A. (2000) Endogenous nitric oxide attenuates erythropoietin gene expression in vivo. Pflugers Arch. 439: 445-448.

37. Schobersberger W, Hoffmann G, Fandrey J. (1996) Nitric oxide donors suppress erythropoietin production in vitro. Pflugers Arch. 432: 980-985.

38. Liu Y, Christou H, Morita T, Laughner E, Semenza GL, Kourembanas S. (1998) Carbon monoxide and nitric oxide suppress the hypoxic induction of vascular endothelial growth factor gene via the $5^{\prime}$ enhancer. J. Biol. Chem. 273: 15257-15262.
39. Huang LE, Willmore WG, Gu J, Goldberg MA, Bunn HF. (1999) Inhibition of hypoxia-inducible factor 1 activation by carbon monoxide and nitric oxide. Implications for oxygen sensing and signaling. J. Biol. Chem. 274: 9038-9044.

40. Genius J, Fandrey J. (2000) Nitric oxide affects the production of reactive oxygen species in hepatoma cells: implications for the process of oxygen sensing. Free Radic. Biol. Med. 29: 515-521.

41. Ankoma-Sey V, Wang Y, Dai Z. (2000) Hypoxic stimulation of vascular endothelial growth factor expression in activated rat hepatic stellate cells. Hepatology 31: 141-148.

42. Zierler K. (1999) Whole body glucose metabolism. Am. J. Physiol. 276: E409-E426.

43. Larsen JJ, Hansen JM, Olsen NV, Galbo H, Dela F. (1997) The effect of high altitude hypoxia on glucose homeostasis in men. J. Physiol. 504: 241-249.

44. Cheng N, Cai W, Jiang M, Wu S. (1997) Effect of hypoxia on blood glucose, hormones, and insulin receptor functions in newborn calves. Pediatr. Res. 41: 852-856.

45. Pison CM, Chauvin C, Perrault H, et al. (1998) In vivo hypoxic exposure impairs metabolic adaptations to a 48 hour fast in rats. Eur. Respir. J. 12: 658-665.

46. Narimiya M, Yamada $H$, Matsuba I, Ikeda YU, Tanese T, Abe M. (1982) The effect of hypoxia on insulin and glucagon secretion in the perfused pancreas of the rat. Endocrinology 111: 1010-1014.

47. Malaisse WJ, Rasschaert J, Zahner D, Sener A. (1988) Hexose metabolism in pancreatic islets: the Pasteur effect. Diabetes Res. 7: 53-58.

48. Ohta M, Nelson D, Nelson J, Meglasson MD, Erecinska M. (1990) Oxygen and temperature dependence of stimulated insulin secretion in isolates rat islets of Langerhans. J. Biol. Chem. 265: 17525-17532.

49. Dionne KE, Colton CK, Yarmush ML. (1993) Effects of hypoxia on insulin secretion by isolated rat and canine islets of Langerhans. Diabetes 42: 12-21.

50. Papas KK, Long Jr RC, Sambanis A, Constantinidis I. (1999) Development of a Bioartificial pancreas: II. Effects of oxygen on long-term entrapment $\beta$ TC 3 cell cultures. Biotechnol. Bioeng. 66: 231237.

51. Dionne KE, Colton CK, Yarmush ML. (1991) A microperfusion system with environmental control for studying insulin secretion by pancreatic tissue. Biotechnol. Prog. 7: 359-368.

52. Dionne KE, Colton CK, Yarmush ML. (1989) Effect of oxygen on isolates pancreatic tissue. ASAIO Transactions 35: 739-741.

53. Papas KK, Long Jr RC, Sambanis A, Constantinidis I. (1996) Effects of oxygen on metabolic and secretory activities of $\beta$ TC3 cells. Biochim. Biophys. Acta 1291: 163-166. 